University of Michigan Law School University of Michigan Law School Scholarship Repository

Articles

Faculty Scholarship

1988

\title{
Some Modest Proposals on the Vice-Presidency
}

Richard D. Friedman

University of Michigan Law School, rdfrdman@umich.edu

Available at: https://repository.law.umich.edu/articles/181

Follow this and additional works at: https://repository.law.umich.edu/articles

Part of the Constitutional Law Commons, Election Law Commons, Law and Politics Commons, and the President/Executive Department Commons

\section{Recommended Citation}

Friedman, Richard D. "Some Modest Proposals on the Vice-Presidency." Mich. L. Rev. 86 (1988): 1703-34.

This Article is brought to you for free and open access by the Faculty Scholarship at University of Michigan Law School Scholarship Repository. It has been accepted for inclusion in Articles by an authorized administrator of University of Michigan Law School Scholarship Repository. For more information, please contact mlaw.repository@umich.edu. 


\title{
SOME MODEST PROPOSALS ON THE VICE-PRESIDENCY
}

\author{
Richard D. Friedman*
}

There are many good things in the Constitution, but the vice-presidency isn't one of them. In Part I of this essay, I will argue that there are three basic problems with the vice-presidency: the method of nomination, the method of election, and the office itself. That just about covers the waterfront. ${ }^{1}$

If we had to do it all over again, we almost certainly would not create the system we currently have. We cannot undo history, but we do have a very strong incentive to develop a better system of succession to the presidency. Whom we choose as vice-president is a matter of great national importance. Nine men have succeeded to the presidency from the second spot, five of them since $1900 . .^{2}$ In this century,

* Professor of Law, University of Michigan Law School. B.A. 1973, J.D. 1976, Harvard University; D.Phil. 1979, Oxford University. - Ed.

My thanks to Michael Carowitz, who provided valuable research assistance in the preparation of this article. Alex Aleinikoff, Ed Cooper, Don Elfenbein, Jerry Israel, and Rick Lempert, together with other participants in the University of Michigan Law Workshop, offered many constructive comments.

Latter-day senators, take note: Parts of this piece are highly speculative. Cf. Bork, Neutral Principles and Some First Amendment Problems, 47 IND. L.J. 1 (1971). If I am ever nominated for high office, I may disavow them.

1. That is not to say that there is nothing good to be said for the office. As my "Successorship Postulate" acknowledges, the vice-presidency does perform one function of great value. See note 38 infra and accompanying text. But as it stands, the office is badly crafted. My aim in this essay is to discuss how it can be better designed to perform its one true function in a manner consistent with our democratic principles. I thus take an intermediate position between those who believe that "[t]he modern vice presidency is, on balance, a healthy institution," Nelson, Background Paper, in A Heartbeat Away: Report of the Twentietr Century Fund TASK ForCE ON THE Vice PRESIDENCY 19, 95 (1988) [hereinafter A Heartbeat AwAy, Background], one that has become "more promising and constructive," Report of the Task Force, in A Heartbeat Away: Report of the Twentieth CentuRy Fund Task Force on the VICE PRESIDENCY 4 [hereinafter A HearTBEat AWAX, Report], and so requires only narrow improvements, and those who believe that the vice-presidency has been proved by "long experience ... to be beyond redemption" and so should be abolished. Heclo, Reuss \& Schlesinger, Comments, in A Heartbeat Away: Report of THE Twentieth CENTURy Fund Task ForCe on the Vice PREsidency 17.

For a careful study that is far more skeptical of the prospects for substantial improvement, and for a fine bibliography, see J. Goldstein, THE MODERN AMERICAN VICE PRESIDENCY: The Transformation of a Polrtical Institution (1982). Other recent works include A Heartbeat Away, Background, supra; M. TuRner, The Vice President as Policy MAKer: RoCKefelleR IN THE Ford WhITE House (1982); P. Light, Vice-Presidential Power (1984); M. Natoli, American Prince, American Pauper: The Contemporary Vice Presidency in Perspective (1985).

2. The nine are John Tyler (1841), Millard Fillmore (1850), Andrew Johnson (1865), Chester 
we have fared reasonably well with vice-presidents who have succeeded to the White House. In various surveys, Theodore Roosevelt and Harry Truman have consistently been ranked as among our best presidents. $^{3}$ But the vice-presidents of the last century who succeeded to the White House, and a substantial number of those in either century who did not, were mediocrities or worse. ${ }^{4}$ Spiro T. Agnew is the most recent example of a narrowly averted disaster, but there have been others.

For example, suppose that Franklin Roosevelt had died in his first or second term instead of his fourth. The man to guide us through the Depression would have been John Nance Garner. No doubt Cactus Jack was an able legislative tactician, and perhaps he did not fully merit John L. Lewis's classic description of him as "a whiskey-drinking, poker-playing, evil old man."5 But he was hardly the inspirational and forward-thinking leader that the people sought and got in Roosevelt. Or suppose that Roosevelt had died during his third term.

A. Arthur (1881), Theodore Roosevelt (1901), Calvin Coolidge (1923), Harry S Truman (1945), Lyndon B. Johnson (1963), and Gerald R. Ford (1974).

3. Arthur M. Schlesinger, Sr., conducted a survey of 55 historians and other "experts" in 1948 , and updated this with a survey of 75 experts in 1962. In 1981, David L. Porter surveyed 41 historians, and the following year the Chicago Tribune polled 49 "leading historians and seminal scholars." Also in 1982, Robert K. Murray and Tim H. Blessing sent a general mailing to professors of American history with doctorates, and the following year reported on the 846 responses they had received. Each of the polls rated each of the presidents who had completed his term by the time of the poll, except for William H. Harrison and James A. Garfield, both of whom died shortly after taking office. Theodore Roosevelt was ranked as near great in both Schlesinger polls and in the Murray-Blessing poll, as great in the Porter poll, and as fourth best in the Tribune poll. Truman was ranked eighth in the Tribune survey and was rated as near great in each of the others. Murray \& Blessing, The Presidential Performance Study: A Progress Report, 70 J. AM. Hist. 535, 535-41 (1983).

4. In addition to ranking Roosevelt and Truman as near-great, the Murray-Blessing survey rated Lyndon Johnson as above average, Ford and Arthur as average, Tyler, Fillmore, and Coolidge as below average, and Andrew Johnson as a failure. Id. at 540. (The other surveys yielded very similar results, except that Andrew Johnson was rated as average in the earlier Schlesinger surveys and as below average in the Porter survey. Id. at 540-41.) In comparison, of the 27 presidents covered by the survey who were elected directly into the office, 4 were rated as great, 2 as near-great, 8 as above average, 7 as average, 2 as below average, and 4 as failures. Id. Overall, 14 directly elected presidents were classified as great, near-great, or above average and 6 as below average or failures, while for those who succeeded to the office the figures were 3 and 4 , respectively.

Similar results emerge from the Chicago Tribune survey. The mean ranking for the presidents who had succeeded from the vice-presidency was 21.1 (T. Roosevelt - 4; Truman - 8; L. Johnson - 12; Ford - 23; Arthur - 24; Coolidge - 27; Tyler - 29; Fillmore - 31; A. Johnson - 32). For the directly elected presidents, the mean ranking was 19.0. Neal, Our Best and Worst Presidents, Chi. Trib., Jan. 10, 1982, § 9 (Magazine), at 9.

One might reasonably conclude from these surveys that, on average, there is a significant, but not overwhelming, difference in quality between presidents who are directly elected and those who succeed from the vice-presidency. There is, of course, no guarantee that any other method of succession would select presidents of as high quality, on average, as those elected in a full-scale national election.

5. J. Wechsler, Labor Baron: A Portrait of John L. Lewis 101-02 (1944) (quoting Lewis). 
Our wartime leader would have been Henry Agard Wallace - a brilliant agronomist, and a person of good will and sometimes sound vision, but plagued with a muddle-headedness best summarized by Dashiell Hammett's comment that "he'd be better off leaving things alone and cross-breeding himself."6

We may not always be so lucky. If I am correct, as I argue in Part $\mathrm{I}$, that the vice-presidency is fundamentally flawed, then we should think seriously about how to improve it. And there is no better time than now, as we approach a presidential election. In Part II, therefore, I offer three simple but far-reaching proposals. Each addresses one of the problems that I have identified. The first proposal is that the vice-presidency not be considered a disqualification from holding another office, at least one in the federal executive branch. This proposal is "serious" in the sense that the next president can and should seriously consider implementing it immediately. No obstacles preclude the core application of this proposal, and it requires no constitutional or other legal change. (It would help to have a constitutional amendment eliminating the vice-president's role as president of the Senate and clearly obviating any constitutional problems; so far as this proposal concerns appointment of the vice-president to a federal executive position, however, I do not believe that such an amendment is necessary. ${ }^{7}$ ) The other two proposals, that the vice-president should be separately nominated and separately elected, are more speculative. The three proposals are modular - they can be adopted independently or in any combination.

\section{Problems of the Vice-Presidency}

A party's choice of its candidate for vice-president is rarely the result of any true democratic process; rather, it is almost always a matter of the presidential nominee's discretion, quickly ratified by a passive convention. ${ }^{8}$ Often, perhaps most often, the vice-presidential

6. L. HELLMAN, SCOUNDREL TIME 124 (1976) (relating a comment by Hammett). Hellman provides strong evidence to suggest that Hammett was correct. Consider that Wallace, immediately after his wedding, left his bride at the church for several hours while he drove off alone in a new Ford his father had just given them. Id. Or that, as Hellman was about to move off the farm that she had owned near Wallace's, the former vice-president gave her, as a going-away present, a fifty-pound bag of manure. Id. at 125-26. The man was definitely weird. See also, eg., T. MORGAN, FDR: A BrograpHY 531-34 (1985) (discussing the so-called "guru letters," which betrayed Wallace's mysticism, lack of discretion, and poor judgment). But cf. N. MARKoWITZ, The Rise and Fall of the People's Century: HeNRY A. Wallace and American LibERALISM, 1941-1948, 333-42 (1973) (sympathetic, but hedged, discussion of the "mysticism legend").

7. See Part II.A.4 and Appendix infra.

8. The last vice-presidential nominee of a major party chosen in an open convention - that is, not effectively selected by the presidential nominee - was Estes Kefauver, who beat out John 
candidate is chosen primarily not because she would be a good president but because she would help make a good ticket, balanced in ideology, geography, experience, and now, perhaps, sex and ethnicity as well. ${ }^{9}$

Furthermore, unless a presidential candidate sews up her own nomination in leisurely fashion, as Jimmy Carter did in 1976, the choice of a vice-president is likely to be hurriedly made, without a chance for searching scrutiny. ${ }^{10}$ As George McGovern learned, the effect of a hurried selection is potentially devastating. ${ }^{11}$ Indeed, even a significant amount of time for the presidential nominee to investigate potential running mates is not enough. A private inquiry is unlikely to shed as much light as the brilliant glare cast by the press and others upon a candidate running in primaries or already nominated to a national ticket; had Walter Mondale known, in July 1984, as much about John Zaccaro's finances as we all learned in August, Mondale probably would have selected someone other than Geraldine Ferraro as his running mate. Our system of nominating most candidates for public office is predicated on the premise that the scrutiny created by a nomination campaign is essential. ${ }^{12}$ If this is so, our system of nominating

F. Kennedy in 1956 for the Democratic nomination after Adlai E. Stevenson, the presidential nominee, declined to make a choice. L. Southwick, Presidential Also-Rans and RunNING MATES 1788-1980, 595 (1984).

9. See, e.g., P. LIGHT, supra note 1, at 4; J. WITCOVER, MARATHON: The Pursuir of ThE PrESIDENCY 1972-1976, 359 (1977). In 1984, Walter Mondale included on his list of finalists for the position one black (Tom Bradley), one Hispanic (Henry Cisneros), one Jew (Diane Feinstein), one Italian-American (Geraldine Ferraro), two women (Feinstein and Ferraro), and one white male representative of the Southern Old Guard (Lloyd Bentsen) - a mix comparable to that of James Watt's ill-described coal-leasing commission. See Beck, James Watt's Last Gaffe?, NewsweEk, Oct. 3, 1983, at 45 ("We have every mix you can have . . . a black . . . a woman, two Jews and a cripple."). See generally Andersen, Looking Out for No. 2: Gender, Geography, and Politics Will Figure in the Veep Selection, TIME, June 18, 1984, at 22; Shapiro, Mondale Kicks Off the Race for No. 2, NewSwEEK, July 2, 1984, at 20. Mondale's eventual choice, of course, was Ferraro. She not only became the first woman nominated for vice-president by a major party but also completed the fourth Democratic ticket in the last seven elections to be headed by one Catholic and one Protestant.

10. Because Carter's nomination for the presidency was virtually assured by the end of the 1976 Democratic primaries, he had the opportunity to make a careful evaluation of several possible running mates in the two months before the Democratic Convention. Carter's staff compiled a list of names, commissioned a poll on the popularity of several possible running mates, conducted background investigations, and arranged for the finalists to meet with Carter. See, e.g., M. Schram, Running for President 1976: The Carter Campaign 200-04 (1977); J. WrTCOVER, supra note 9 , at 359-68.

11. McGovern's nomination by the Democratic Party in 1972 was not assured until the convention. Hence, his choice of Thomas Eagleton as his running mate was made hastily and with little more background check than to ask Eagleton himself whether he had any "skeletons in the closet." McGovern and his party were caught unaware when journalists revealed that on three occasions Eagleton had received electric shock treatments for depression and fatigue. Eagleton was eventually forced of the ticket, but not before the incident seriously wounded the already troubled McGovern campaign. See L. SouTHWICK, supra note 8, at 661-64.

12. Not that even the publicity of a national campaign is enough to guarantee complete expo- 
vice-presidents is gravely deficient.

As unsatisfactory as the process for nominating the parties' candidates is, the process for choosing the vice-president from among the candidates is even worse. In fact, there is no true independent choice, for under the twelfth amendment the same electors, who almost invariably are party loyalists, vote for both president and vice-president. ${ }^{13}$ Accordingly, the selection of the vice-president becomes a marginal factor in deciding the presidential election to which it is tied. ${ }^{14}$

Finally, the office of the vice-presidency is itself unsatisfactory. Constitutionally, there is very little to it atl. ${ }^{15}$ The vice-president is

sure. Spiro Agnew had twice been elected vice-president before his peccadilloes as governor of Maryland came to light. See Presidential Succession: Ford, RockefelleR \& THE 25TH AMENDMENT 30, 32 (L. Sobel ed. 1975).

13. U.S. CONST. amend. XII. The twelfth amendment governs selection of the vice-president in ordinary course. When a vacancy occurs in the vice-presidency, the nomination and ratification procedure of the twenty-fifth amendment - which offers even less opportunity for democratic selection - comes into play.

14. See Schlesinger, On the Presidential Succession, 89 PoL. ScI. Q. 475, 488 (1974) ("part of a tie-in sale"). This is potentially troublesome not only because it essentially deprives the voters of a genuine choice for vice-president, but also for a reciprocal reason; if the vice-presidential candidate is decisive in determining anybody's vote, then that vote is not cast for the presidential candidate whom the voter prefers. Of course, if one believes that a ticket must be indivisible, then it follows that a voter not strongly inclined to one presidential candidate over the other may reasonably let the tail wag the dog, voting on the basis of her vice-presidential preference. For reasons stated in Part II.B infra, I do not accept the premise of indivisibility; at least its merit is not self-evident, and the possibility of a presidential choice being determined by vice-presidential preferences must be counted as one of its costs. See Schlesinger, supra, at 484 ("Very likely Johnson made a difference in 1960."); Will, Why Not Make It a Real Job?, NEwswEEK, Mar. 14, 1988, at 68 (Johnson is the only vice-presidential nominee who "probably was essential to the success of a ticket.").

15. The vice-presidency worked its way into the Constitution almost inadvertently. Under a plan proposed by Alexander Hamilton, the president of the Senate would succeed if the position of chief executive became vacant. 1 M. FARRAND, RECORDS OF THE FEDERAL CONVENTION OF 1787, 292, 300 (1911) [hereinafter M. FARRAND, RECoRDS]. The Committee of Detail adopted this proposal, 2 id. at 186, but some other members of the convention objected, fearing that the Senate, which was then expected to play a role in the election of the president, might be obstructive if its own president would succeed in case of vacancy. Id. at 402-03, 427. More fundamentally, the convention disliked the proposed election of the president by the legislature, for fear that it would make him too dependent on that branch. Id. at 113, 501 .

The matter of presidential election and succession was referred to a special committee of eleven. That committee reported out a system nearly identical to the one eventually adopted. Electors chosen by each state would cast votes for two persons, at least one of whom must not be from the elector's state. The top vote-getter would be elected president, assuming he was named by a majority of the electors, and the second would become vice-president. Id. at 493-94. The vice-president would preside over the Senate, and would succeed to the presidency in case of vacancy. Id. at 495 .

The Convention adopted plural voting for fear that if each elector had only one vote he would cast it provincially, for a citizen of his own state. See id. at 113. Apparently the vice-presidency was created only in part to provide a successor to the presidency; the second office also attractively completed the two-vote scheme. Indeed, in agreeing that there was no need for a vicepresident, Hugh Williamson claimed that "[h]e was introduced only for the sake of a valuable mode of election which required two to be chosen at the same time." Id. at 537. See A HEARTBEAT AWAY, Background, supra note 1, at 26 (vice-presidency created to attach a consequence to the second votes to assure that they "would not be used frivolously"). The vice-president's 
officially the presiding officer of the Senate, but that has long meant little; ${ }^{16}$ even the Framers anticipated that this would be a no-show job. ${ }^{17} \mathrm{He}$ casts a deciding vote if the Senate is tied, but the vote cannot truly be considered his own; do not bet the bank on the prospect that George Bush will break any ties by voting against the Reagan administration's position. ${ }^{18}$

Nor have time and tradition added sufficient functions to the meager fare given the vice-president by the Constitution. Presidential candidates often promise to keep their vice-presidents gainfully employed, but their record is poor. ${ }^{19}$ True, recent vice-presidents have assumed a

role as president of the Senate appears to have been incidental, in part a remnant of the original plan of succession, $c f$. id. at 537 (Gouverneur Morris comments that absent a vice-president the president of the Senate would succeed), and in part to give him some work. Id. (Roger Sherman: "If the vice-President were not to be President of the Senate, he would be without employment. ..."); see also id. at 639 (George Mason: Vice-president, "who for want of other employment is made president of the Senate," is unnecessary, resulting from failure to create a better scheme of succession).

For a fuller history of the creation and early history of the vice-presidency, see Schlesinger, supra note 14.

16. See Schlesinger, supra note 14, at 479 ("[T]he Vice President's constitutional employment soon became a farce."). As a candidate for the vice-presidency in 1920, Franklin Roosevelt urged that the office be given more significant responsibility; its Senate duties, he noted, were "largely perfunctory." Roosevelt, Can the Vice President be Useful?, SAT. EvE. PosT, Oct. 16, 1920, at 8; cf. A HEARTBEAT AwAY, Background, supra note 1, at 33 ("Garner was the last vice president to fulfill the office of Senate president diligently."). In the House of Representatives, the Speaker has a great deal of power. By contrast, the vice-president has very little. A good explanation for the difference is probably that the vice-president is an interloper. Unlike the Speaker, he is not a member of the body, see notes 71-75 infra and accompanying text - indeed, he is essentially part of another branch, see notes $71,79-87$ infra and accompanying text - and he has not been chosen as presiding officer by the members.

17. See 2 M. FARRAND, RECORDS, supra note 15, at 537, 639 (comments of Sherman and Mason, noting that vice-president is made president of the Senate only to keep him employed.). U.S. ConST. art. I, $\S 3$, cl. 5 reads: "The Senate shall chuse their other Officers, and also a President pro tempore, in the Absence of the Vice President, or when he shall exercise the Office of President of the United States." By contrast, in providing for the election of the Speaker and other officers of the House, the Framers did not see the necessity of reminding the House to choose an alternate in case the Speaker should be absent or unable to continue in office. U.S. CoNST. art. I, $\S 2$, cl. 5.

18. Cf. Sherrill, HHH as Uncle Tom. RAMPARTS, June 29, 1968, at 26, $28-29$ (describing how Vice-President Humphrey, apparently under orders from Johnson, issued a crucial ruling in favor of filibusters, notwithstanding that throughout his Senate career he had adopted the opposite position). Moreover, the vice-president cannot vote to create a tie. Nor is he a factor on those motions that require supermajorities of the voting senators - which under the Constitution include votes to ratify a treaty, to override a veto, and to propose a constitutional amendment, and under the Senate's rules include motions for cloture of debate.

19. "Gerald Ford, like his predecessors, entered into the office with soothing presidential assurances that he, unlike his predecessors, would be given tasks of substance and responsibility. One could be absolutely certain that these shining prospects would disappear whenever he reached out to grasp them.... The more gifted and ambitious the Vice President, the more acute his frustration - and the less his President is inclined to do to alleviate it." Schlesinger, supra note 14, at 478, 486. See also J. GoldsTEn, supra note 1, at 309 (Rockefeller told the Senate that the vice-presidency "cannot be said to have sorely tried either my talents or my stamina."); A HEARTBEAT AWAY, Background, supra note 1, at 62 (Rockefeller's lament: "I go to funerals, I go to earthquakes."). 
greater array of functions, and have been given larger staffs for support, and occasionally vice-presidents are able to exercise genuine influence; the old cliché that the vice-presidency is an empty job has been replaced by the new wisdom that the job is far more substantial than it used to be. ${ }^{20}$ But, for the most part, the job has changed far more in visibility than in actual power, ${ }^{21}$ and "Humphrey's Law" still applies: "He who giveth can taketh away and often does."22 Lacking any reliable, independent power base, vice-presidents are kept in political limbo. ${ }^{23}$ Lyndon Johnson, not surprisingly, put the point most vividly. "Boys," he once reported, "I've just reminded Hubert that I've got his balls in my pocket."24 LBJ, a former vice-president himself, was in a position to know. ${ }^{25}$

20. E.g., Goldstein, Van Buren's "Jinx," N.Y. Times, May 28, 1988, at 15, col. 6. The most notable case of vice-presidential effectiveness is probably Walter Mondale. Mondale and President Carter appear to have had a strong personal affinity. Moreover, Mondale's long experience in the Senate was a particularly strong asset in a White House whose staff was notable for its lack of Washington insiders. For discussions of his unprecedented role, see M. NATOLI, supra note 1, at 176-80; P. LIGHT, supra note 1, at 201-20. Nelson Rockefeller also was able to have substantial infuence as vice-president, in large part because of the unique situation in which he served. M. TURNER, supra note 1, at 180-84. For general discussions of the growing role of the vicepresidency, see J. GoLDSTEIN, supra note 1, at 134-201; P. LIGHT, supra note 1.

21. A. Sindler, Unchosen Presidents: The Vice-President and Other FrustraTIONS OF PRESIDENTIAL SUCCESSION 37 (1976) (acknowledging increasing importance of "the modern vice presidency," but characterizing the change as slow, uneven, and "more in the sense of greater prominence and publicity than power").

22. Humphrey, Changes in the Vice Presidency, 67 Current Hist. 58, 59 (1974); "For all the newfound influence of the office, vice presidential power is still largely a function of the president's willingness to confer it." A HeARTBEAT AwAY, Background, supra note 1, at 23.

23. Note the 1986 assessment by a former Republican Cabinet member of Vice-President Bush: "George's problem is that he is a kind of political moon, who generates no light of his own. He has reflected Ronald Reagan's brilliance so far, but now that sun may be setting." Apple, The Iran Affair: A Presidency Damaged, N.Y. Times, Nov. 26, 1986, at A1, col. 5, A12, col. 6 .

24. D. Halberstam, The Best and the Brightest 533 (1972). "Rarely would a high public official undergo the humiliation and virtual emasculation that Humphrey underwent as Vice-President, almost, it seemed, from the very start." Id. Humphrey is not the only vicepresident to whom such imagery has been applied. See M. KRAMER \& S. ROBERTS, I NEVER WANTED TO BE VICE-PRESIDENT OF ANYTHING! 7 (1976) (noting that the vice-presidency was the "emasculating stand-by equipment" Rockefeller had feared); note 25 infra (comments that Johnson as vice-president was shriveled and shrunken); text at note 26 infra (Bush seen as a "wimp"); Schlesinger, supra note 14, at 485 (the vice-president is an "impotent . . outsider"); id. at 486 (Bill Moyers: the vice-presidency is a "man eater").

25. "Johnson had no intention of protecting Humphrey from that special misery he had suffered as Vice-President, but rather intended to pass it on in even greater doses." D. HALBERSTAM, supra note 19, at 533. As vice-president, Johnson "felt that he would simply shrivel up." D. KEARNS, LYNDON JoHnson AND THE AMERICAN DREAM 165 (1976). See also Schlesinger, supra note 14, at 486 ("Johnson was a subdued and shrunken man by 1963."). During the 1950s, he had been one of the most powerful people in America. "Lyndon Johnson runs the Senate," Humphrey told then Senator-elect Joseph Clark in December 1956, "and will treat you well." J. Clark, Congress: The Sapless Branch 2 (1964). Soon after inauguration, he was already a figure of mild ridicule in Camelot. "I'd like to say something if I may," he interposed in a conversation in The First Family (Cadence Records, 1962), a tremendously popular album based principally on mimicry of President Kennedy. "Must you, Lyndon?" the President responded. 
George Bush, too, has been constantly plagued by the so-called "wimp factor."26 However much this can be attributed to his own political personality, a significant cause is the nature of his job. ${ }^{27}$ The vice-presidency demands loyalty above all else; perfect loyalty demands perfect congruence with the president's views; and such congruence tends to make the less visible partner nearly totally invisible, with no separate identity. ${ }^{28}$

Perhaps the situation was somewhat exaggerated in the Gershwin musicals of the 1930s, Of Thee I Sing and Let 'Em Eat Cake, in which virtually nobody could remember the name of the vice-president. ${ }^{29}$ But the exaggeration was less than we might wish. Nobody told Harry Truman about the atomic bomb until after Franklin Roosevelt's death. ${ }^{30}$ Thus, at the most crucial succession by a vice-president in history, Truman was abysmally prepared for the very contingency that justified his office.

Vice-presidents are better briefed these days, but note this intriguing sentence from the report of the congressional committees investigating the Iran-contra affair: "The Vice President attended several meetings on the Iran initiative, but none of the participants could recall his views." 31

The vice-presidency does, of course, have one very significant attraction; by becoming vice-president, virtually any politician improves

"Like every Vice President before him, [Johnson] found himself stifled in the Vice-Presidency, reduced to the role of an onlooker, in office but out of power." D. KEARNS, supra, at 164. Although he did have some satisfying responsibilities on civil rights matters, Johnson's verdict on his tenure as vice-president was clear: "I detested every minute of it." Id.

26. Warner, Bush Battles the "Wimp Factor", NEwSWEEK, Oct. 19, 1987, at 28.

27. Cf. Rothenberg, In Search of George Bush, N.Y. Times, Mar. 6, 1988, $\S 6$ (Magazine), at 29, 48 ("All modern Vice Presidents have been immensely frustrated in their jobs, to be sure. But none [before Bush] felt completely constrained from at least offering opinions within the confines of the White House.").

28. "Bush had explicitly pledged his loyalty to Ronald Reagan when he was offered the Vice Presidency. After the 1980 election, he made that oath the center of his political existence. Not only would he never be seen or heard disagreeing with President Reagan on any matter, but he also would never publicly offer any substantive opinions of his own." Id.

29. Alexander Throttlebottom. Of Thee I Sing, music by G. Gershwin, lyrics by I. Gershwin, book by G. Kaufman \& M. Ryskind (Knopf 1932); Let 'Em Eat Cake, music by G. Gershwin, lyrics by I. Gershwin, book by G. Kaufman \& M. Ryskind (Knopf 1933) (sequel to Of Thee I Sing).

30. H. TRUMan, Year of Decisions 10-11 (1955).

31. N.Y. Times, Nov. 19, 1987, at A1, col. 6, A10, col. 3 (quoting from the majority report of the Iran-contra committees) (emphasis added). Asked during the 1960 campaign whether Richard Nixon had participated in any major decisions during the more than seven years of their tenure, President Eisenhower gave the now famous reply, "If you give me a week, I might think of one." Schlesinger, supra note 14, at 478. And Nixon himself, when asked whether he had told Spiro Agnew about plans for the diplomatic opening to China, responded in an "incredulous" tone: "Agnew? Agnew? Oh, of course not." Id. (quoting Washington-Star News, May 16, 1974). 
his chances of eventually becoming president, but not so much by election as by succession - in recent years, present and past vice-presidents have been very successful at being nominated for the presidency and mostly unsuccessful at being elected to it. ${ }^{32}$ Even a politician who very much wants to be president may find the passive actuarial approach to the White House a bit ghoulish. It is not surprising that, for many of our most prominent public figures, the prospect of "all or nothing at all" has had little appeal, and that many have forsaken the chance to fill out the bottom of a ticket. ${ }^{33}$ The situation has improved in recent years, for the vice-presidency is considerably more attractive than in prior times, but even today some strong potential candidates are uninterested. ${ }^{34}$

That the designated successorship to the presidency is spurned by able people who may be suited for, and presumably would welcome,

32. "In a twist of irony, the very devotion to the president that wins the vice president kudos among fellow partisans may invite rejection by the broader electorate in the general election; the voters may regard the vice president as lacking the independent character and vision they seek in their presidents." A HeARTBEat AWAY, Background, supra note 1, at 39.

33. For example, Charles Evans Hughes, the enormously popular governor of New York, rejected William Howard Taft's request that he be Taft's running mate on the 1908 Republican ticket. "Hughes could see no challenge whatever in the Vice Presidency and felt that, without a compelling reason, he could not afford to make the financial sacrifice it would entail." $1 \mathrm{M}$. PusEy, ChaRles EVANS Hughes 239 (1951). In 1924, the Republican convention went so far as to nominate, as Calvin Coolidge's running mate, former Governor Frank Lowden of Illinois, who had been a serious candidate for the presidential nomination in 1920 and would be a less serious contender in 1928. Lowden declined the honor, however, saying he would not want to become president by "walking slowly behind the hearse of some other man." L. SouTHwick, supra note 8, at 502. In 1936, Senator Arthur Vandenberg of Michigan also refused an offer of the Republican vice-presidential nomination, id. at 533, as did Governor Earl Warren of California in 1944 - although four years later, with more favorable prospects for a Republican victory, Warren accepted Thomas Dewey's offer, $i d$. at 572. Also in 1948, Justice William O. Douglas turned down an offer to be Harry S Truman's running mate. D. HEALY, AMERICA's VICEPRESIDENTS 189 (1984). As governor of New York, Nelson Rockefeller turned down offers to fill out the Republican ticket in 1960 and the Democratic ticket in 1968. J. DESMOND, NELSON Rockefeller: A Polmical BIOGRAPHY 277 (1964) (offer from Nixon in 1960); J. Persico, THE IMPERIAL ROCKEFELlER 81 (1982) (offer from Humphrey in 1968); M. KRAMER \& S. RoBERTs, supra note 24, at 74 (1960 and 1968 offers). (Only later, no longer governor and without the burden or uncertainty of having to win an election, did Rockefeller accept the vicepresidency.) Also in 1968, Sen. Edward Kennedy withdrew from consideration for the Democratic vice-presidential nomination, N.Y. Times, July 27, 1968, at 1, col. 3, weeks before abandoning hope that the party would nominate him for the presidency. Id., Aug. 29, 1968 at 21, col. 8. A substantial portion of the Democratic Party declined entreaties from George McGovern in 1972 to run for vice-president. In 1980, former President Ford ultimately decided not to join Ronald Reagan on the Republican ticket because Reagan was unwilling to accede to Ford's demands that he be accorded genuine power as vice-president.

34. See, e.g., Dionne, Dukakis Visits Capitol Hill Looking for a Running Mate, N.Y. Times, June 30, 1988, at 14. col. 5 (in a visit to Capitol Hill, Dukakis "was reminded that the Vice Presidency is not the world's most desirable job. . . . Nunn was one of several top Democrats to make it clear he didn't want the Vice Presidency"); Berke, Dukakis Rules Out Bradley, Almost, N.Y. Times, June 25, 1988, at 7, col. 1 (Dukakis will probably respect the wishes of Bill Bradley not to be the Democratic vice-presidential candidate.). 
the presidency itself is a defect in our political system. ${ }^{35}$ And when such people do accept the vice-presidency, they reveal two other defects: The job is a waste of their talents, ${ }^{36}$ and holding it is arguably "much less a making than a maiming experience. ... [F]ar from preparing them for the succession, [it] is more likely to erode their capacity to succeed." 37

\section{Proposals}

The problems of the vice-presidency can, I believe, be solved by working from two simple postulates.

The Successorship Postulate. The valuable function of the vice-president in our constitutional scheme is to be available to assume the presidency immediately should a vacancy occur, ${ }^{38}$ and nothing more. ${ }^{39}$

35. Under a sound system, "an uncompleted presidential term [would] be completed by a successor of presumed presidential quality"; "[o]ften, though not invariably, [such persons] would have competed for a presidential nomination and shown some solid popular and party appeal." A. SINDLER, supra note 21, at 8-9. Our system was previously poor, and is now spotty, in producing vice-presidents of such "presumed presidential quality." See A HEARTBEAT AwAY, Background, supra note 1, at 44 ("Around half the vice presidential nominees in Ithe 1948-1984] period already had sought or been prominently mentioned for the presidency at the time they were picked.").

36. Mr. Dooley's caricature of the vice-presidency was more accurate in his day than it is now. See F. DunNe, The Vice-President, in Dissertations BY Mr. Dooley 115, 115 (1906) ('Th' prisidincy is th' highest office in th' gift iv th' people. Th' vice-prisidincy is th' next highest an' th' lowest. It isn't a crime exactly. Ye can't be sint to jail f'r it, but it's a kind iv a disgrace. It's like writin' anonymous letters."); E. MORRIS, THE RISE OF THEODORE ROOSEVELT 737 (1979) ("Theodore Roosevelt's formal services to the nation as Vice-President lasted exactly four days, from March 4 to March 8, 1901. The Senate then adjourned until December, and Roosevelt was free to lay down his gavel and return to Oyster Bay.") (footnote omitted). But even in modern times, for all the extra visibility of the job, it does not offer much to satisfy an energetic and intelligent political leader. See, e.g., notes 19-28 supra and accompanying text.

37. Schlesinger, supra note 14, at 485; see Will, supra note 14 ("The inherent awkwardness of the office may take a toll not only on the political prospects but the souls of some occupants, even - no, especially — of large-souled people like LBJ and Hubert Humphrey."); E. GoldMaN, THE TRAGEDY OF LYNDON JOHNSON 264 (1969) (misery and demeaning nature of vice-presidency "may well . . . seriously corrode his potential for effective leadership in the future.").

38. Some commentators doubt the value of this function; indeed, proposals for elimination of the vice-presidency have gained respectable support. See, e.g., Schlesinger, supra note 14. If the office were eliminated, a vacancy in the presidency would be temporarily filled by another officer, and a special presidential election would have to be arranged hastily. Such a system has substantial merit, but it also has obvious problems. First, how soon should the election be held? It takes time to elect a president - at least the way we now do it, with the electorate rather than professionals selecting each party's candidate. See A HEARTBEAT AWAY, Background, supra note 1, at 84 ("unlike France, presidential selection in the United States is an inherently lengthy undertaking"). A rushed election, while the nation is still traumatized by the death of its leader, is hardly the ideal way to choose a successor. Thus, the shorter the interim period, the more inadequate the electoral process for the new president. The longer the interim, the more time the presidency will be in limbo, occupied temporarily by an officer not selected with presidential succession principally in mind (unless she were selected after the presidency became vacant but that would temporarily leave a total vacuum at the top of the Government). Indeed, the longer the interim, the greater the need for a previously designated successor - which is what I contend the vice-president should be.

Second, how long should the term of the special election winner be? If it lasts only to the end 
The Democracy Postulate. Selecting the person to succeed to an uncompleted presidential term is a political decision of paramount importance, essentially equivalent in significance to the choice of a president through the ordinary electoral route. Whether the choice of a successor is to be made before or after the need arises, ${ }^{40}$ it should resemble, to the extent possible, the usual choice of a president in one fundamental respect: The free choice of the people should control, unfettered by artificial restrictions. This is not because the people will necessarily make the best choice, but because there is no way of knowing whether any other choice is better, and because only such a free choice squares with our fundamental values of democracy and equality. 41

From these postulates, three proposals for action emerge. They may be applied together or independently, for each is aimed at one of the three problems of the vice-presidency - nomination, election, and function once elected. I will discuss these in reverse order.

of the original term, it might not be worthwhile to hold the special election if the term were nearly expired. Whenever the vacancy occurred, this system would add the burden and distraction of an extra presidential election to our political cycle. Furthermore, this system is likely to generate an extra transition, which may be destabilizing; alternatively, distaste for that sort of instability might induce voters in the special election to retain the interim president, even if she would not otherwise be their choice.

Perhaps, at least if the president left office late enough in her term, the special election should be for a full term, or even (to avoid permanent alteration of the political cycle) for the unexpired term plus a full term. But the longer the special term, and the later in the original term that it begins, the more a special election becomes an inferior and unnecessary replacement for the next regularly scheduled election.

Perhaps, nevertheless, elimination of the vice-presidency will in the end prove to be the best possible option. But prudence counsels that we recognize the one function of enormous value that the vice-presidency has served, and so hesitate to eliminate it altogether before considering less drastic alternatives. See On the Threshold of the White House, ATLANTc MoNTHLy, July 1974, at 63, 70 [hereinafter Threshold] (Birch Bayh: "I believe we ought not perform radical surgery on the Constitution without reasons far more pressing than those [Schlesinger] introduces .....").

39. I put aside as basically trivial the various ceremonial functions performed by the vicepresident. Who would perform these if the vice-president were not available to do so? Counterparts of the same people who helped preserve the nation during the eighteen periods, totalling nearly 38 years, in our history in which the office was vacant. (Vice-Presidents Clinton, Gerry, Calhoun, Tyler, Fillmore, King, A. Johnson, Wilson, Arthur, Hendricks, Hobart, Roosevelt, Sherman, Coolidge, Truman, L. Johnson, Agnew, and Ford all left the office, by succession, death, or resignation, before the end of their terms, J. GoLDSTEIN, supra note 1, at 229; only with the passage of the twenty-fifth amendment has there been a mechanism, already invoked with the appointments of Ford and Rockefeller, to name a replacement.) See Will, supra note 14 ("[If] a vice president [given] a serious job, such as secretary of state . . . . would then be too busy to attend funerals, so be it. Send the secretary of commerce.").

40. See note 38 supra.

41. See Schlesinger, supra note 14, at $503 \mathrm{n} .81$ (adopting principle that "democracy implies as few restrictions as possible on a people's right to choose its rulers."). 


\section{A. The Vice-Presidency Should Not Be a Bar to Holding Any Other Office Simultaneously}

\section{Elimination of the Legislative Vestige}

The essential function of the vice-president is to serve as designated successor to the president, and nothing more. The simplest solution to the problem of the office, therefore, is not to eliminate $i^{42}$ or to make work specifically for it. Rather, the office should carry with it only the successorship function, and the vice-president should be allowed to perform other tasks consistent with that function. Thus, the vice-president's role as presiding officer of the Senate should be eliminated. The elimination would be akin to an appendectomy - it would require a significant operation, in this case a constitutional amendment, but it would remove a vestige of no benefit ${ }^{43}$ and substantial potential harm. ${ }^{44}$

That is only part of the desirable change, however. The other part is both more crucial and, at least in its most significant aspect, far easier to accomplish. Because the only true function of the vice-presidency is to provide a standby, the vice-president ought to be allowed to hold another political office. The value of this proposal is clearest with respect to offices in the executive branch of the federal government. Accordingly, I shall first make this strongest case. I then shall suggest that the same idea might well be extended to seats in Congress or to state political offices.

\section{The Core Proposal: Offices Within the Federal Executive Branch}

My core proposal is that the vice-president be allowed to hold a political position in the executive branch - not just a seat on the National Security Council, or head of some blue ribbon panel, and not an assignment carved out of the jurisdiction of other officers, but a preexisting job of real power and importance, such as a Cabinet office, or head of OMB, or the White House Chief of Staff. ${ }^{45}$ The specific job should not be attached to the vice-presidency; rather, the president

42. See note 38 supra.

43. Without the vice-president, the Senate would simply select its own presiding officer, as does the House. On tie votes, the proposal would fail, as it does in the House. And the Republic would survive.

44. The harm would arise if the vice-president's function in the Senate were held or feared to be a constitutional obstacle to the vice-president's ability to hold other political office.

45. Others have proposed that, in one form or another, the vice-president be given more substantial executive responsibility. See A HEARTBEAT AWAY, Background, supra note 1, at 67 ("Such proposals have been offered for many years."); Roosevelt, supra note 16; Will, supra note 14; Schlesinger, supra note 14, at 482 (proposal of Carl Kaysen); Threshold, supra note 38, at 67 (comment of John Sparkman); note 92 infra. 
should be allowed to select a job suited to the talents of the particular vice-president, who should be appointed to the position in the same manner that anyone else would be. In essence, the proposal is that a person's position as designated successor to the president should not disqualify that person from serving in a significant office in the administration.

Allowing the vice-president to fill such an office would have several significant advantages. It would virtually ensure that the vice-president is not merely sideline equipment, but a key member of the administration. That would mean that the capacity of the vice-president who, we hope, is well suited to be president - would not be wasted. And it would almost certainly mean that the vice-president, having already served as an integral member of the administration, would be better prepared to serve as president if necessary. ${ }^{46}$ In this respect, our system would be brought closer to that of other democracies - indeed, of other governments - that are able to make a peaceful intraparty transition of power without an intervening election: The new chief executive is nearly always one of those who held substantial executive responsibility in the previous administration. And that is as it should be. ${ }^{47}$

In addition to these benefits, and in large part because of them, the vice-presidency would be unambiguously attractive to an ambitious politician of presidential caliber. Becoming vice-president would no

46. The majority of the Twentieth Century Fund Task Force made the contrary argument, that an executive position "focuses the vice president's attention on one policy area, ... reducing the vice president's general preparedness for succession." A HEARTBEAT AWAY, Report, supra note 1 , at 11 . This argument ignores the option of a broad ranging assignment such as White House Chief of Staff, underestimates the breadth of concerns addressed by the State, Treasury, and Defense Departments, among others, and overestimates the importance of substantive experience in a given policy area; it was not Abraham Lincoln's record in the Mexican War that made him a great wartime leader.

Walter Mondale claimed that the vice-presidency "may be the best training of all [for the presidency]." Cronin, Rethinking the Vice-Presidency, in RETHINKING THE PRESIDENCY 324, 338 (T. Cronin ed. 1982). But Mondale's relationship with Jimmy Carter and his standing within the administration were unusual, see supra note 20 . The regression since has shown that, without the institutionalization that comes from a formal assignment to a well-defined job, the vice-presidency cannot be relied upon as a genuine training ground for the presidency.

47. It is interesting that during six periods in our history the Secretary of State or another member of the Cabinet has been next in line to be president. Under the Presidential Succession Act of 1886, ch. 4, 24 Stat. 1, if both the president and vice-president died or were otherwise unable to serve, the succession would run through the Cabinet. The law was changed in 1947, in response to the belief of Harry Truman that the president should always be an elective officer, not someone chosen by his predecessor. See Brown \& Cinquegrana, The Realities of Presidential Succession, 75 GEO. L.J. 1389, 1417-23 (1987). Truman's objection was only to the method by which the designated successor was chosen - not to that successor's service in the Cabinet. Indeed, the vice-president was made a member of the National Security Council at Truman's initiative and with his signature. See A HEARTBEAT AWAY, Background, supra note 1, at 35; National Security Act Amendments of 1949, ch. 412, 63 Stat. 578, 579 (codified as amended at 50 U.S.C. $\S 402$ (1951)). 
longer mean gambling one's entire political career, for it would offer real power immediately and a substantial possibility of the ultimate advancement.

Finally, once one president named the vice-president to a genuine executive position, future presidents would be expected to do likewise, ${ }^{48}$ and candidates would be expected to announce what executive positions their running mates would have. This would put extra pressure on a presidential candidate to complete the ticket with someone clearly perceived as capable of handling a big job. And it would give voters a better glimpse than they now have of the probable shape of each party's potential administration. ${ }^{49}$

\section{Political Objections}

What costs are there in allowing the vice-president to assume a major office in the executive branch? I think there are virtually none. 50

Michael Nelson has argued that "should the expectation that the vice president will perform an executive assignment become institutionalized, it may warp the criteria for vice presidential selection. The qualifications of a good agency head or staff director may be different from the qualifications of a worthy successor president."51 This argument is unpersuasive because the proposal is not to attach any particular job to the vice-presidency. Surely any person capable of being a successor president is capable of handling some other significant job in government.

Sometimes the argument is made that giving the vice-president a genuine appointive office would tend to divide the executive power. ${ }^{52}$ It is hard to see, though, how the vice-president can be a rival to the

48. Walter Mondale's influence as vice-president had little precedential value for his successor, but that is because it was a behind-the-scenes matter, dependent on the personal relationship between Mondale and Jimmy Carter. See supra note 20. But once one vice-president were given a formal and visible position, such as head of a Cabinet department, succeeding presidents who did not do likewise would appear to have no confidence in the vice-president. $C f$. P. LiGHT, supra note 1 , at 165 (vice-president has "a certain permanence" in West Wing because of political damage to a president who moved him out).

49. This might not always be true if we adopt either of the suggestions made in Sections II.B and II.C infra, that the vice-president be separately nominated and elected. But, at least when the two were of the same party, the president would probably disappoint public expectations if she failed to name her designated successor to a major executive position.

50. I do not count the ceremonial function heavily. See note 39 supra.

51. A Heartbeat Away, Background, supra note 1, at 68-69.

52. See C. Rossiter, The American Presidency 140 (2d ed. 1960) (recanting an earlier proposal, made in Rossiter, The Reform of the Vice-Presidency, 63 PoL. SCI. Q. 383 (1948), that some administrative responsibilities be transferred from the president to the vice-president, because the vice-president is "not subject to the power of removal," and so the office would be "a dagger aimed constantly at the precious unity of the executive power"). 
president as long as the president can remove the vice-president from the appointive position, reducing him, if she pleases, to his minimal constitutional function of presiding over the Senate.

This assumes, of course, that as a practical as well as a legal matter the president could remove the vice-president from the appointive office, or reassign him to another job. The president might hesitate to create the appearance, if not the reality, of firing his own designated successor. ${ }^{53}$ And so the president would have a problem, with two aspects. One would be the embarrassment of having to "bite the bullet," removing an extremely close associate in whom she had previously shown great faith. In this respect, the problem resembles, and is not necessarily greater than, one the president would have if she had appointed to the Cabinet, and now wanted to remove, her brother or a close friend, or someone with a strong political constituency. This is an ordinary type of political problem, not a sufficient reason to keep the vice-president from having meaningful responsibility in the first place.

The other aspect of the problem has no real parallel in these other situations; even after being dismissed from the other executive position, the vice-president remains the designated successor to the president, and so poses a continuing potential embarrassment. But the problem is not inevitable, and neither should it be intimidating. This view is fortified by examining perhaps the most important historical case in which a vice-president was given a formal and significant policymaking role. ${ }^{54}$ On the eve of World War II, President Roosevelt made Henry Wallace head of the Economic Defense Board, which after Pearl Harbor was renamed the Board of Economic Welfare. The Board had real responsibilities in procuring and stockpiling strategic materials, and Wallace, over resistance from the State and Commerce Departments, tried to use it to advance goals of international social justice and postwar planning. Wallace was occupying turf that had belonged to others, however, and he lacked emollient political skills. After a dispute with Secretary of Commerce Jesse Jones flared in public in 1943, Roosevelt swiftly removed both men from their special wartime assignments. ${ }^{55}$ This episode has no bearing on the ability of a more politically deft vice-president to work successfully in a significant

53. See, e.g., Schlesinger, supra note 14 , at 482 .

54. There have been other cases. President Ford appointed Nelson Rockefeller supervisor of the Domestic Council, but did not give him full control over the Council's staff, and Rockefeller increasingly distanced himself from the Council's activities. See M. TURNER, supra note 1, at 5263, 158-63.

55. For discussion of Wallace's tenure on the Board, see J. WALKER, HeNRY A. WALLACE AND American Foreign Policy 94-97 (1976), and N. Markowitz, supra note 6, at 65-73. 
policymaking job, one that was previously established and so does not detract from other officeholders' expected powers. It does show that a president can remove a vice-president from a policymaking assignment without suffering a debilitating political blow.

Contrary to myth, dismissing Wallace caused FDR no devastating embarrassment; ${ }^{56}$ indeed, according to one of his most discerning biographers, "Roosevelt's sternness impressed the country."57 Certainly Roosevelt did not act as if Wallace's continuing as vice-president was mortifying. He gave Wallace other work, a sensitive and well-publicized diplomatic mission to the Far East. 58 Intense pressure from conservative Democratic leaders, fears of a divided party, and the anticipated loss of a million or more votes persuaded Roosevelt not to insist in 1944, as he had in 1940, on the determinedly liberal Wallace as his running mate. ${ }^{59}$ But Roosevelt's personal preference was still for Wallace, ${ }^{60}$ and he even wrote a letter to that effect to the convention chairman. ${ }^{61}$ The endorsement was clearly lukewarm, and other characteristically Rooseveltian manipulations favored the eventual nominee, Harry Truman. ${ }^{62}$ But the key point is that, although Roosevelt could easily have precluded Wallace's renomination, he did not do so; in fact, Wallace led after the first ballot. ${ }^{63}$ After his defeat, Wallace campaigned vigorously for the Democratic ticket. ${ }^{64}$ Before the election, Roosevelt promised Wallace his choice of any cabinet post except Secretary of State in the next administration. ${ }^{65}$ The promise may have been disingenuous, but Roosevelt lived up to it: Wallace requested the Commerce Department, Roosevelt made room by firing Wallace's nemesis, Jones, and Wallace was confirmed with the timely

56. See, eg., Hertzberg, Bar Nunn, THE NEw Republic, May 23, 1988, at 16 ("FDR . . . endured a year of embarrassment."); Why Two Hats Don't Fit a Vice President, NewsweEk, May 2, 1988, at 20 (quoting Richard Neustadt that Wallace's firing was a "major embarrassment").

57. J. Burns, Roosevelt: The Soldier of Freedom 342 (1970).

58. See, e.g., J. Burns, supra note 56, at 542; E. SChapsmeier \& F. SchapsMEIER, Prophet in Politics: HeNRy A. WAllace AND THE WAR Years, 1940-1965, at 84-97 (1970); J. WALKER, supra note 55, at 105-11.

59. See T. MORGaN, supra note 6, at 725-29; S. RosenMAN, WorkING WITH RoOSEvelT 441 (1952); T. Sirevag, The Eclipse of the New Deal and the Fall of Vice President WALLACE, 1944, at 140-43, 146-53 (1985). at 111 .

60. See N. MiLler, FDR: AN INTIMATE HistoRY 499 (1983); J. WALkER, supra note 55,

61. See J. BURNS, supra note 57, at 506; N. MARKowITZ, supra note 6, at 105.

62. E.g., J. BuRNS, supra note 57, at 503-06; T. MorgaN, supra note 6, at 725-30, 744.

63. T. SIREVAG, supra note 59 , at 156.

64. N. MARKowITZ, supra note 6, at 126-27.

65. The Price of Vision: The Diary of Henry A. Wallace, 1942-1946, at 82 (J. Blum ed. 1973). 
help of Harry Truman. ${ }^{66}$ It would be difficult to find in this record the type of profound embarrassment that should make future presidents leery of making optimal use of their vice-presidents. ${ }^{67}$

Giving the vice-president new responsibilities adds complexity to our political system, and any complexity creates the potential for problems as well as for benefits. ${ }^{68}$ But eliminating such potential problems requires undue restrictiveness. Potential political problems of the ordinary sort should not, under an "if you breathe you may catch germs" mentality, automatically preclude possibilities offering great public benefit. ${ }^{69}$

\section{Constitutional Objections}

A constitutional amendment should not be necessary to allow the vice-president to assume an office of major significance in the executive branch. The only plausible constitutional objection appears to be that, because the vice-president is president of the Senate (until the adoption of the amendment suggested above, eliminating that function), taking on an executive position would violate the principle of separation of powers. ${ }^{70} \mathrm{I}$ do not believe this objection has any real merit.

66. J. BuRNS, supra note 57, at 561; N. MARKowITZ, supra note 6, at 129-34; J. WALKER, supra note 55, at 112-14. Before Wallace expressed his preference for Commerce, Roosevelt had told Wallace he planned to fire Jones.

67. See, e.g., M. TURNER, supra note 1, at 22 ("The precedent strongly supports the contention that presidents may have little to fear from their vice presidents.").

68. For example, "[a]n executive position may place the vice president in an uncomfortable and publicly adversarial relationship with both the president and other appointed officials." A HearTBEAT AwAy, Report, supra note 1, at 11. But that potential exists for anyone appointed to high office; if it appears intolerable for a vice-president that may be because we have grown accustomed to thinking of lack of identity as a job criterion for the vice-presidency. The president would probably still be able to avoid or limit antagonism with the vice-president, as he now is generally able to do with most of his Cabinet. And even if not, the antagonism presumably would not prevent the vice-president from receiving the most significant briefings, or seriousiy affect his ability to succeed if the president leaves office before the end of the term.

69. For example, one with a solemn imagination could easily point to potential problems if a general or a judge harbors hopes of becoming president. We do not for that reason disqualify from the presidency any former general (Washington, Jackson, and others less luminary) or judge (Jackson, again, and Taft).

70. An objection might also be raised that the Senate could not properly discharge its "advice and consent" function, because senators might be afraid to oppose their own presiding officer. The argument is essentially frivolous. Politics are not hermetically sealed; legislators must often make decisions that affect a colleague who is in a position to reward friends and punish enemies. Indeed, the Senate has repeatedly been asked to confirm presidential nominations of its own members to executive or judicial positions; the nomination of Edmund Muskie as Secretary of State is a recent example. Such nominations are usually treated generously, according to the custom of senatorial courtesy, but they are not for that reason rendered invalid. And an ordinary senator is more likely than the vice-president to be able to take vengeance on another senator who opposes him. (Of course, under the proposal made here, a vice-president would remain as president of the Senate even if confirmed to the other executive position for which she was nominated, but that does not appear to matter very much for purposes of this argument, especially because of the powerlessness of the vice-president in the Senate.) In any event, this objection 
The argument does have a superficially plausible textual basis in the so-called incompatibility clause, art. I, $\S 6, \mathrm{cl}$. 2, of the Constitution, which provides that "no Person holding any Office under the United States, shall be a Member of either House during his Continuance in Office." If the vice-president is a "Member" of the Senate, then he cannot hold an executive office. ${ }^{71}$ It is quite certain, however, that the vice-president is not a "Member."

For one thing, he probably should already be deemed, simply by virtue of being vice-president, to hold an "Office under the United States."72 Assuming this is so, then he cannot be a "Member," be-

would not apply to positions, like that of White House Chief of Staff, that do not require Senate approval.

71. See Nunn (Broad) vs. Jefferson (Narrow), Wall St. J., May 5, 1988, at 24, col. 1 (citing incompatibility clause as a constitutional problem for appointment of the vice-president to an executive position, and raising the question of whether the vice-president is a "member of the legislative branch"). Michael Nelson has recently made another textual argument that "substantive executive powers cannot, in view of Article II, be delegated responsibly to any constitutionally independent official." A HEARTBEAT AWAY, Background, supra note 1, at 68. The vicepresident would, however, be subject to removal from the appointive office in the same manner as anyone else who held it. Besides, Article II does not prevent Congress from giving executive power to officeholders appointed by the president but not subject to removal by him; it should make little difference if the guarantee of independence is constitutional rather than statutory.

72. Constitutional text and history suggest that the vice-presidency is an "Office." Under art. II, $\S 4$, the impeachment process applies to the vice-president, and under that clause and art. $I, \S 3$, one of the consequences of that process is removal "from Office." In debate at the Constitutional Convention, George Mason referred to "the office of vice-president," 2 M. FARRAND, RECORDS, supra note 15, at 537; see also id. at 639 ("officer"); and very late in its proceedings the Convention adopted an amendment making the impeachment procedure applicable to "[t]he Vice President and other civil Officers of the United States." Id. at 545, 552. Thus the matter was referred to the Committee on Style, id. at 574, which reported back a reformulation, substantially identical to the eventual art. II, $\S 4$, making the procedure applicable to "[t]he President, vice-president, and all civil officers of the United States...." Id. at 600 . There is no indication that the changed language was meant to suggest that the president and vice-president were not "officers of the United States." Indeed, the twelfth amendment, ratified in 1804 while the Constitution was still very young, also explicitly refers to the vice-presidency as an office. (Also, under its most sensible reading, $\S 3$ of the fourteenth amendment treats the vice-presidency as an "office ... under the United States").

The issue becomes somewhat cloudier if analysis rests on "[t]he classic definition of an office in the constitutional sense," Memorandum Opinion for the Counsel to the President, $1 \mathrm{Op}$. Off. Legal Counsel 125, 125 (1977), the definition formulated in a statutory context in United States v. Hartwell, 73 U.S. (6 Wall.) 385, 393 (1867): "An office is a public station, or employment, conferred by the appointment of government. The term embraces the ideas of tenure, duration, emolument, and duties." Probably not much weight should be put on the term "appointment," but cf. Buckley v. Valeo, 424 U.S. 1, 131 (1976) (per curiam) (stating - but in a context involving the appointment power - that the term "Officers of the United States" was "taken by all concerned to embrace all appointed officials exercising responsibility under the public laws of the Nation"), and the other elements of the Hartwell definition seem, for the most part, to include the vice-presidency. The position clearly has tenure and duration. As for emoluments, the vicepresident's pay appears to be linked to the Senate presidency rather than to any executive office, see 5 U.S.C. $\S 2106(1982)$, but he now receives staff support, 3 U.S.C. $\$ 106$ (1982), and an expense allowance, 3 U.S.C. $\S 111$ (1982), in conjunction with executive activities. The vicepresident has no duties prescribed by the original constitution, apart from the Senate presidency, and as late as 1939 he had no real role in the executive branch. Memorandum Opinion for the Attorney General, 1 Op. Off. Legal Counsel 54, 58 (1977). But now, by constitutional amendment, statute, and presidential directive, he has been given a wide range of executive duties, 
cause if he were, then by creating the vice-presidency the Constitution would also have created a violation of the incompatibility clause. ${ }^{73}$ But even if the vice-president is not deemed to hold an "Office under the United States," it seems indisputable that he cannot be a "Member," for if he were the Senate could expel him, under art. I, $\S 5$, and other clearly unanticipated results would follow. ${ }^{74}$ Furthermore, the vice-president plainly cannot be considered a senator, for under the original language of art. I, $\S 3$, as well as under the seventeenth amendment, the Senate is "composed of two Senators from each State."75 It requires far less linguistic contortion to consider the vicepresident as the president but not a member of the Senate than to consider him as a member of the Senate but not a senator.

But more than textual analysis is necessary to answer the constitutional question. The incompatibility clause has been "universally understood" as a protection of the separation of powers, and in particular as "a safeguard against executive influence on Members of

including the responsibility of serving as acting President in the event of temporary presidential disability. Individually, some of the vice-president's duties might be considered too narrow or ephemeral to constitute an "Office under the United States," but in the aggregate they do. After "a number of years [in which] the Vice President [drew] on executive agencies to assist him in discharging his responsibilities to assist the President," H.R. REP. No. 994, 91st Cong., 2d Sess. 17 (1970), Congress recognized the vice-president's continuing executive function by providing him with his own staff for that purpose. Executive Offices Appropriation Act of 1971, Pub. L. No. 91-422, 84 Stat. 876; see Departments of Treasury and Post Office and Executive Office Appropriations, 1970: Hearings Before the Subcommittee on Departments of Treasury and Post Office and Executive Office Appropriations of the House Comm. on Appropriations, 91st Cong., 2d Sess., pt. 3, at 185-92 (description and discussion of the growing executive role of the vicepresident).

73. Under one plausible view, the vice-presidency is not constitutionally an "Office under the United States," but has become one by the practice of recent decades. Cf. note 72 supra. Under this view, classifying the vice-president as a "Member" of the Senate would not be a contradiction in constitutional terms, but would mean that for some time the vice-president has been in violation of the incompatibility clause.

74. For example, also under art. I, $\S 5$, the Senate would be the judge of the election and qualifications of the vice-president, and the vice-president would be counted as a member in determining the number necessary to make a quorum or to demand the yeas and nays of the Senate on any question. Furthermore, the vice-president would presumably be counted in determining the number of senators' votes necessary to convict a person on impeachment, under art. I, $\S 3, \mathrm{cl} .6$, and perhaps also to override a veto, under art. I, $\S 7, \mathrm{cl} .2$, or to propose a constitutional amendment, under art. V, although under art. I, $\S 3$, cl. 4 , he would not vote himself unless the Senate were equally divided, in which case his vote on these questions would be inconsequential. See also ANNALs of CoNG., 81 (1803) (8th Cong., 1st Sess., published in 1852) (Sen. Robert Wright: "In the eye of the Constitution [the Vice President] is not a member of the Senate at all."); id. at 82 (Pierce Butler, a Framer: "It was never intended by the Constitution that the Vice President should have a vote in altering the Constitution."); $c f$. C.F. RIDDICK, Senate Procedure: Precedents and Practices, S. Doc. No. 97-2, 97th Cong., 1st Sess. (1981), at 1125 (vice-president may break a tie on the adoption of an amendment to a proposed constitutional amendment).

75. The seventeenth amendment also explicitly provides that "each Senator shall have one vote." This clause, of course, clearly does not apply to the vice-president. 
Congress."76 The concern underlying the clause is not invoked by giving executive power to the vice-president, for the vice-president is already active in the executive branch. Indeed, he is most sensibly identified with that branch, if his "center of gravity" has to be placed on one side of the line or the other: $77 \mathrm{He}$ is ordinarily elected simultaneously with, inseparably from, in the same manner as, and principally as a standby for, the president. That the Constitution gives him a legislative duty may be regarded as either an anomaly - making him already a walking violation of the separation of powers doctrine ${ }^{78}$ or as evidence that the Framers did not take that doctrine quite so literally as is sometimes supposed. ${ }^{79}$

Although the Framers recognized the mixed nature of the vicepresidency, ${ }^{80}$ and President Washington occasionally asked Vice-President Adams to attend Cabinet meetings, ${ }^{81}$ until recently most presidents and vice-presidents have adopted the view of Adams' successor. "I consider my office as constitutionally confined to legislative functions," wrote Thomas Jefferson, "and that I could not take any part whatever in executive consultations, even were it proposed." 82 Calvin Coolidge was the first vice-president to attend Cabinet meetings regu-

76. Library of Congress, Congressional Research Service, Constitution of the UNITED STATES OF AMERICA: ANALYSIS AND INTERPRETATION, S. DOC. No. 82, 92d Cong., 2d Sess. 123 (1973); accord, Dionisopoulos, A Commentary on the Constitutional Issues in the Powell and Related Cases, 17 J. PuB. L. 103, 111 (1968) ("This prohibition was considered necessary by the Founding Fathers to prevent undue influence by the executive in legislative proceedings."); Reservists Comm. to Stop the War v. Laird, 323 F. Supp. 833, 836 (D.D.C. 1971), affd. mem., 495 F.2d 1075 (D.C. Cir. 1972), revd. sub nom., Schlesinger v. Reservists Comm. to Stop the War, 418 U.S. 208 (1974); THE FEDERALIST No. 76, at 496 (A. Hamilton) (Modern Library ed. 1937) (clause establishes "important guards against the danger of executive influence upon the legislative body").

77. Garner placed the vice-presidency in "a no man's land somewhere between" the two branches, while Mondale said that he was a member of both branches. A HEARTBEAT AWAY, Background, supra note 1 , at 23-24.

78. While vice-president, Gerald R. Ford wrote, "In finding something for the Vice President to do besides stand and wait, the Founding Fathers violated their own fundamental rule of separation of powers. The Vice President is a constitutional hybrid. Alone among federal officials he stands with one foot in the legislative branch and the other in the executive." Threshold, supra note 38, at 63 .

79. Some members of the Convention did worry about the mixed nature of the vice-presidency. See 2 M. FARRAND, REcordS supra note 15. Elbridge Gerry feared the vice-president's role in the Senate would effectively make the president head of the legislature. Id. at 536-37. Gerry - who incidentally was elected vice-president in 1812 - wrote, "The V.P [sic] destroys the Independce. of the Legislature." Id. at 635. Mason "thought the office of vice-President an encroachment of the rights of the Senate; and that it mixed too much the Legislative \& Executive, which as well as the Judiciary department, ought to be kept as separate as possible." Id. at 537. He viewed the office of vice-president as "dangerously blending the executive and legislative powers." Id. at 639. But by an 8-2 vote of the states the Convention overcame their objections. Id. at 538.

80. See note 79 supra.

81. Schlesinger, supra note 14 , at 480.

82. J. Feerick, From Failing Hands: The Story of Presidential Succession 70 
larly, but Coolidge's successor, Charles G. Dawes, refused to do so, claiming that such involvement in executive affairs would be a "wrong principle."83

In recent decades, however, both the executive and legislative branches have progressively regarded the vice-president as principally an executive officer. Well before giving Henry Wallace the economic warfare job, Franklin Roosevelt reinstated the practice of regular vicepresidential attendance at Cabinet meetings, and it is now routine. ${ }^{84}$ Similarly, the 1949 legislation giving the vice-president a seat on the National Security Council ${ }^{85}$ clearly suggests the executive nature of the office. It is confirmed by the various other boards and commissions on which he now sits. Most importantly, though, it is confirmed and strengthened by his office and staff arrangements. Beginning with Lyndon Johnson, vice-presidents maintained an office in the Executive Office Building, and during the Carter and Reagan administrations the vice-president has worked even closer to the president, in the West Wing of the White House, just a few steps from the Oval Office. ${ }^{86}$ Furthermore, Congress now provides him with rather substantial administrative support explicitly for the "performance of functions specially assigned to the Vice-President by the President in the discharge of executive duties and responsibilities . . . ."87

The development I propose would allow the vice-president to exercise compulsory rather than mere advisory power, supervisory authority over thousands or millions rather than dozens of people, and responsibilities that someone else would have to perform if he did not. Undoubtedly, this development would make the vice-presidency a

(1965) (quoting Jefferson). Jefferson apparently took this self-effacing stance so that he could be free to build his own political party. A HEARTBEAT AWAY, Background, supra note 1, at 28.

83. Schlesinger, supra note 14 , at 480.

84. Id. at $480-81$.

85. National Security Act Amendments of 1949, ch. 412, § 3, 63 Stat. 578, 579 (amending 50 U.S.C. \& 402(a) (1982)).

86. M. NATOLI, supra note 1 , at 178,180 ; P. LIGHT, supra note 1 , at $68,76-77,162-65,207-$ 08, 263-65. Spiro Agnew briefly had an office in the West Wing but did not hold it for long, in large part because he was isolated from his own staff. Id. at 76-77.

87. 3 U.S.C. $\S 106$ (1982); see generally supra note 72. But cf. Schlesinger, supra note 14, at 480 (both Truman and Eisenhower wrote in their memoirs that the vice-president is not part of the executive branch). Indeed, the more interesting argument now is not whether the vice-president is part of the executive branch, but to what extent he is part of the legislative branch. With respect to the vice-president's pay and senatorial staff, he is still treated as a member of the legislative branch. See, e.g., 5 U.S.C. \$ 2106 (1982). In 1961, some Democratic senators supported the idea of making Vice-President-elect Lyndon Johnson - who until then had been their leader and was about to begin presiding over the body - as chairman of the Senate Democratic Conference. The proposal foundered on the objection that this would violate the separation of powers. Cronin, supra note 46 , at 328. 
more important office than it already is, but not a more executive office than it already is.

Thus, there is no constitutional incompatibility in the vice-president being both the president of the Senate and a genuine appointive officer in the executive branch. But even if there were, that would not end the matter. I contend that the vice-president might yet be able to hold the executive appointment by relinquishing the legislative assignment. Furthermore, a litigant seeking to exclude the vice-president from the executive position would have difficulty overcoming political question and standing barriers, and even if successful could expect only prospective relief, not the invalidation of any prior actions. These points take us rather far afield, and so I reserve them for an Appendix. For now it is enough to state the bottom line; fears of unconstitutionality should not dissuade a president from appointing the vice-president to a genuine executive position.

\section{The Prospect Extended: Other Political Offices}

It is harder to make the case that the vice-president ought to be allowed to hold a congressional or state political office. But I think the case can be made. In principle, there is no reason to limit to the federal executive branch the public functions that a person can fill while also serving as standby to the president. Suppose that continuing to serve as governor of her state strikes a potential vice-presidential nominee as the most productive service she can perform while also standing ready to step into the presidency. It may be unfortunate to preclude that possibility and so deter her from accepting the nomination. 88

Some situations might create complaints about the dual roles. For example, if the governor spent too much time out of state being briefed as vice-president, some of her home-state voters might be upset. But this does not seem all that different from the problem that we now have when governors spend time out of state running for president. 89

88. Allowing such a possibility to a governor or senator in mid-term would make running for vice-president a no-lose proposition. Similarly, incumbents who expected reelection would not have to give up their current offices to become vice-president; they could run for both positions simultaneously. LBJ did this, successfully, in 1960, and then yielded his Senate seat in favor of the vice-presidency.

Presumably, a vice-president of the president's own party would more often wish to hold a job in the administration rather than one outside. But in Part II.B of this essay, I suggest that the president and vice-president ought to be elected separately. To a vice-president who is a political opponent of the president, the opportunity to hold a significant position outside the administration may be important.

89. Some grumblings of this sort have been heard against Michael Dukakis, Governor of Massachusetts, during his campaign for the 1988 Democratic nomination. 
That situation is not ideal but we accept it, rather than restricting democracy artificially by taking current governors out of the pool of potential presidential nominees. No doubt some voters and legislators would also complain if the chairman of the Senate Budget Committee were also the designated successor to the president. But again, that situation is not so different from one that might easily arise, and be tolerated, under our current system - if, for example, the president is an old colleague, friend, and ardent political supporter of the chairman. Moreover, if the potential conflict in a particular case really seems dangerous to the people, they can refuse to vote for a potential budget chairman as vice-president; given the Democracy Postulate, 90 it is unclear why this decision should be made for them, in advance and in per se fashion, by the constitution-makers.

Presumably, a constitutional amendment would be required to allow the vice-president to hold an ordinary seat in Congress. ${ }^{91}$ An amendment might also clarify the ability of the vice-president to serve as an official of her home state; the Constitution's utter silence on this prospect could indicate that the Framers found it acceptable, or that they found it inconceivable.

Perhaps the extension of this idea beyond the federal executive branch is fanciful, but I hope the core of my proposal will be considered seriously, and immediately; ${ }^{92}$ the next president should feel free to name his vice-president to a significant and powerful position in his administration. Indeed, I would like to see it as an expected part of presidential campaigns that the presidential candidates announce what office they would have their vice-presidents fill. There is no valid constitutional reason barring such a development, which offers a practically unmixed blessing to our political system. We should not let inertia prevent it from becoming a reality.

90. See text at notes $40-41$ supra.

91. As discussed in note 72 supra and accompanying text, the vice-president should probably be considered an officer of the United States, and so be barred by art. I, $\$ 6$, from being a member of either House. Also, the vice-president's constitutionally prescribed tie-breaking function would likely be construed to bar him from also sitting and voting as an ordinary senator, and his general role as president of the Senate would probably bar him from holding a seat in the House of Representatives.

92. In fact, since this article was drafted - but completely independently of it - this idea has been discussed a great deal. See, e.g., the articles cited in note 56 supra; Drew, supra note 34, at 80 ("A lot of people with nothing better to do have argued that Dukakis should also offer Nunn the role of Secretary of Defense ...."). 


\section{B. The Vice-President Should Be Elected Separately from the President}

I am now going to range further into the speculative realm: I propose a constitutional amendment to provide for the separate election of the president and vice-president. ${ }^{93}$

The idea is not so strange; currently, many states elect their governors and lieutenant governors separately. Such a system is firmly grounded in common sense. Who shall be president and who shall be vice-president are two separate questions, and the best candidates are not necessarily on the same ticket. By alloying the two questions, both are corrupted. ${ }^{94}$ As the Democracy Postulate ${ }^{95}$ suggests, filling the vice-presidency is a question ideally suited for the electoral process, and binding it to another matter is an artificial restriction fundamentally anti-democratic in nature. Indeed, it seems likely that in some elections - 1956 and 1968, for example - the voters would have split their tickets, had they been given the simple democratic option to do so. ${ }^{96}$ History will likely confirm the impression that in each of those years the other vice-presidential candidate would have been an improvement. Providing separate election of vice-presidents would ensure that the candidates are of sufficient stature to face the electorate on their own, that the winner is truly the voter's choice and not a mere coattail clutcher, and that she retains such independent standing that she could not be regarded as a virtual nonentity while serving as standby.

If in fact the public does exercise its option of splitting the ticket, we would then have what some political observers have long felt we lack, a recognized "leader of the opposition."97 That may be to the

93. Under the twelfth amendment, the same electors vote for president and vice-president. U.S. CONST. amend. XII. The key step, of course, is the choice of the electors. Accordingly, my proposal is that, assuming the electoral college idea is maintained, separate electors be chosen for president and for vice-president. Alternatively, if we move to a system of popular election, I would propose that separate tallies be held for the two offices.

94. Ordinarily, if the presidential candidate of one party and the vice-presidential candidate of the other party are the more popular, the winning ticket will be that of the favored presidential candidate. But that is not always so. See note 14 supra.

95. See text at notes $40-41$ supra.

96. In 1956, the winning vice-presidential candidate was Richard Nixon and the loser Estes Kefauver. In 1968, the winner was Spiro Agnew and the loser Edmund Muskie.

97. See, e.g., C. Hardin, Presidential Power and Accountability: Toward a New Constitution 64 (1974); W. WILSON, Congressional Government 76-80 (Meridian ed. 1958). The development proposed in Part II.A, that the vice-president be allowed to hold other office, would apply even if she and the president were of different parties. Sometimes, especially in periods of emergency, a vice-president of one party might hold an executive position under a president of the other party, thus helping to form a sort of coalition government. Probably more often in split-ticket situations, however, the vice-president would not have a role in the administration. In that circumstance, her status as the only member of her party elected by the public 
good. But would intolerable problems also be created? I do not believe so.

Some might object to the possibility that a vice-president would succeed to the White House in the middle of the term to which a president of the other party had been elected. The objection is not compelling. For one thing, ticket balancing and the loose nature of our political parties prevent even the present system from guaranteeing similarity on the same ticket; historically, several of the successions by vice-presidents have represented dramatic ideological shifts. ${ }^{98}$ More decisively, the objection is anti-democratic. If the electorate is more interested in the character and leadership abilities of its executives than in their ideologies, it is no business of the constitution-makers to dictate that they must sacrifice quality in order to guarantee ideological continuity. ${ }^{99}$ Election of a split ticket may indicate that the public is not all that concerned about particular issues, and wishes to make its choice on other criteria. And the transition from, say, a conservative president to a liberal successor need be no more chaotic in midterm than on a scheduled Inauguration Day; ${ }^{100}$ presumably a new president would not shift gears suddenly if the success of her program demanded restraint.

Second, some might object that, with a president of one party and a vice-president of the other, there would be a greater temptation to impeach and remove the president, or to declare him disabled under the twenty-fifth amendment. The experience of Watergate, however, demonstrates the flimsiness of this concern. Inherent in our system is enormous resistance to removal of a president. A Congress controlled by the party opposed to the president's must be extremely cautious lest it appear to be acting out of purely partisan motives. Public scrutiny is, and would remain under the system I propose, a strong guarantee against partisan-based impeachments or disability declarations. ${ }^{101}$

Election of a president and vice-president of opposing parties

nationwide would very probably make her the effective leader of the opposition, whatever other post she held.

98. Virtually the entire Cabinet resigned shortly after John Tyler succeeded William Henry Harrison. Theodore Roosevelt led the nation in a direction far different from that of his predecessor, William McKinley. The same could probably be said of Andrew Johnson and Abraham Lincoln, but they were not truly of the same party. Johnson, like some other Democrats, joined with the Republicans in a coalition, the National Union Party, for the 1864 election.

99. See Threshold, supra note 38, at 68 (Endicott Peabody, arguing in favor of a special election for vice-president in case of vacancy, notes that the winner might not be of the president's party, but answers that "if it was the will of the people, who could object?").

100. Id. at 68-69.

101. Also, to make a disability determination stick against an unwilling president, he would have to be opposed not only by the vice-president but also by two-thirds of each house and, unless Congress designates a different group, a majority of the department heads. 
would entail one significant cost; in that case, the vice-president's likely position as an adversary rather than a supporter of the administration team would probably diminish or nullify one of the potential benefits cited in support of the suggestion made in Part II.A - the ability of the vice-president to play a key role in the administration that she could suddenly be called on to head. That possibility is unfortunate, though it does offer some compensating benefits. ${ }^{102}$ Presumably, much of the electorate will take it into account before splitting their tickets. In any event, it is not sufficient to deprive the people of the democratic opportunity to designate a potential presidential successor of their choice. ${ }^{103}$

Separate election of vice-presidents would restore the process to something close to the original conception of the Framers. Under the original plan, by which each elector cast two votes for the presidency and the candidate with the second highest total was elected vice-president, the vice-president was to be a person of presidential caliber who had demonstrated independent national standing. The first two vicepresidents, John Adams and Thomas Jefferson, both elected under this system, were two of the most extraordinary statesmen in our history. ${ }^{104}$ The system collapsed, not because of the split ticket of 1796 in which the Federalist Adams and the Republican Jefferson were the two top vote-getters, but because of internal Republican confusion or intrigue in 1800.105 A technical corrective was clearly needed, not a change in the fundamental conception of the vice-presidency. But the twelfth amendment supplied both. Ironically, it did so by making a rather narrow change in the electoral mechanism. The amendment retained a single electoral college and provided that the electors could

102. See note 97 supra and accompanying text.

103. The current tie of presidential and vice-presidential elections may offer our system one other benefit; a vice-presidential candidate who would have difficulty being elected independently, because of some form of prejudice, might be a successful coattail clutcher, and as vicepresident would then have a much improved chance of eventually becoming president. Thus, uncoupling the presidential and vice-presidential elections might diminish the chance of having, say, a woman or a black president. But this impact is by no means clear, for the uncoupling may well facilitate the vice-presidential nomination of such a person. A presidential candidate now reluctant to select a black running mate for fear of losing the votes of some bigots may be willing to do so if those voters can split their tickets. And the coattail effect may yet affect other voters strongly enough to pull the vice-presidential candidate through the election.

104. They and Martin Van Buren are the only sitting vice-presidents to have been elected into the presidency.

105. For whatever reason, Jefferson and Aaron Burr, who was supposed to be the vice-presidential candidate, received the same number of electoral votes. As a result, the election was decided, after an extended deadlock, by the Federalist-controlled House. For helpful accounts of the episode, see Cunningham, Election of 1800, in 1 History of AMERICAN Presidential Elections 1789-1968, 101 (A. Schlesinger ed. 1971); D. MALONE, JefFERSON AND THE ORDEAL OF LIBERTY 489-505 (1962). 
vote separately for president and vice-president; to win the vice-presidency in the ordinary case, one needed a majority of the votes cast for that office - not, as previously, the second highest number of votes cast for the presidency. Because the key step is the selection of electors, the amendment assured that the choice of the vice-president would be a subsidiary and largely ignored question tied to the choice of the president. In retrospect, it seems clear that two electoral colleges, one for each office - or, if the electoral college is to be abolished, separate popular elections - would reinstitute the original conception of the Founders without causing the type of chaos that required alteration of their handiwork.

Making the election of vice-presidents more democratic does not guarantee that better vice-presidents will be chosen. But it does guarantee that if we choose a poor vice-president it is because we as a populace have made a poor choice, not because we have denied ourselves the democratic opportunity to choose.

\section{Nomination of Vice-Presidential Candidates Should Be Made by Delegates Chosen for That Purpose}

Even if one dreads the prospect of a president and vice-president of different parties, it is difficult to object to giving the people a democratic choice in the selection of both candidates. Convention rules, therefore, should provide for the selection of a second set of delegates to vote on the vice-presidential candidate. The selection process for this slate should be modeled in each state after that of the presidential delegates.

It may be objected that the choice of a vice-presidential candidate should be largely up to the presidential nominee and that, in any event, it makes no sense to worry about the bottom of the ticket before the top is settled. But to the extent the public sees merit in these suggestions, they will be reflected in the primary and caucus voting. Those voters enthusiastic enough about one presidential candidate to be willing to leave the choice to her will vote for a slate of delegates so pledged. ${ }^{106}$ Those voters primarily concerned that the vice-presidential candidate, whoever he is, represent a particular viewpoint will choose ideologically oriented slates. And those voters interested in bringing one candidate to prominence may vote for her delegates, so that at last it will truly be possible to run for the vice-presidency. ${ }^{107}$

106. Indeed, there is no reason why a presidential candidate could not have two slates - one for her for the presidency, the other for her choice for the vice-presidency - composed of the same people.

107. Very likely, there would be some candidates running, at least in form, for the presidency 
The probable result is that the convention would be receptive to the presidential nominee's choice, without being a rubber stamp, and that I believe is as it should be. ${ }^{108}$ The certain result is that the selection of the person "a heartbeat away" will be made more democratic, and that is clearly as it should be. ${ }^{109}$

These three proposals attack each of the three problems of the vice-presidency - nomination, election, and the job itself. Each would be useful independently, but they would be most effective if instituted together, allowing the democratic selection of a person well qualified to perform the office's true standby function, but not relegating that person to a mere standby role. Any one of them would be a major change, and major changes in the nation's political fabric should be made hesitantly. But the stakes in improving our system of presidential succession are great. Inertia should not bar at least the simplest development that $\mathrm{I}$ have proposed, allowing the vice-president to hold a genuinely powerful policymaking job in the federal executive branch. To some extent, indeed, inertia - which in its broad sense includes the tendency of things in motion to continue moving in the same direction - favors this development. In recent years, the movement has been to give some executive functions to the vice-president. My argument is that much more motion in the same direction is desirable.

but with a better chance of winning vice-presidential delegates. In the 1988 Democratic primaries, for example, some voters might have chosen Dukakis' presidential delegates and Gore's vice-presidential delegates.

108. If there are two separate categories of delegates, the question arises as to how the convention should perform its functions other than selecting nominees, such as adoption of the platform. One solution is to restrict the vice-presidential delegates to their role of selecting the vicepresidential nominee. Alternatively, the rules may give them fractional votes on other issues, or give them full votes but simply provide for the selection of far more presidential delegates.

109. This too would be consistent with state practice. Even states that tie together the election of the governor and lieutenant governor give party voters the ability to nominate candidates for the two offices in separate primary votes. At the state level, separate nominations can occasionally lead to a fiasco such as befell Adlai E. Stevenson III in 1986: Stevenson renounced the Democratic nomination for governor of Illinois after voters of his party nominated supporters of Lyndon Larouche for lieutenant governor and secretary of state. That was essentially an ambush, a product of low voter turnout for a one-shot primary. A comparable debacle would not be a serious possibility at the federal level. If any fringe candidate gained early success in a vicepresidential campaign, mainstream voters would be almost certain to turn out in large numbers in the subsequent primaries and caucuses. 


\section{APPENDIX}

This appendix proceeds from the assumption (which of course I regard as unfounded) that it is constitutionally incompatible for the vice-president to be both the president of the Senate and a genuine appointive officer in the executive branch. Given this assumption, what are the consequences?

First, the vice-president might very well relieve the hypothetical incompatibility by resigning from, or allowing himself to be disqualified from, the presidency of the Senate. True, art. I, $\S 3$ provides that the vice-president "shall be" president of the Senate. But it also expressly contemplates that he may not act as such, and of course most often he does not. It may well be, therefore, that the vice-president could formally resign the Senate presidency without disturbing his status as designated successor to the president. ${ }^{110}$ Indeed, it seems probable - assuming arguendo that the Senate presidency renders the vice-president a "Member" of the Senate - that the Senate, as "the Judge of the ... Qualifications of its own Members" under art. I, § 5 of the Constitution, could disqualify him from his legislative role but could not affect his executive status. ${ }^{111}$ The loss of the tie-breaking vote may or may not be tolerable to the administration.

But now assume that the vice-president does not jettison the legislative role, and that the Senate takes no action. A litigant would have serious difficulties in reaching a judgment on the merits of the asserted incompatibility. For one thing, a claim under the incompatibility clause may well be a nonjusticiable political question, on the theory that the clause states a qualification for membership in Congress, and so is textually committed by art. I, $\S 5$ to "[e]ach House" for enforcement. The Supreme Court has twice explicitly avoided this issue, in Powell v. McCormack ${ }^{112}$ and Schlesinger v. Reservists Comm. to Stop the War. ${ }^{113}$ The Justice Department has twice - per Solicitor General Bork in Reservists and in an opinion of the Office of Legal Counsel in the Carter administration - taken the view that the incompatibility

110. A resignation letter should be addressed to the president pro tempore of the Senate. There is no danger that this letter would be deemed also to be a resignation from the vicepresidency, because under 3 U.S.C. $\S 20$ (1982), "[t]he only evidence of . . . a resignation of the office of ... Vice President, shall be [a signed instrument] delivered into the office of the Secretary of State."

111. The power of the Senate to judge the qualifications of its own members presumably would not be deemed to extend to the power to declare that its president had disqualified himself from being the successor to the presidency. But $c f$. 1 A. HiNDS, PRECEDENTS OF THE HouSE OF REPRESENTATIVES 603 (1907) (House resolution, 1863, that an officer of the United States who takes a seat in Congress "is thereby . . . out of the office previously held . . ..").

112. 395 U.S. 486,520 \& n.41 (1969).

113. 418 U.S. $208,214-15$ (1974). 
clause is for Congress alone to enforce. ${ }^{114}$

District Judge Gesell's opinion in Reservists, which was adopted by the Court of Appeals but was reversed by the Supreme Court on the standing issue about to be discussed, took a contrary view. But even that opinion seems to weigh against judicial action in the case hypothesized here. Judge Gesell held justiciable the issue of whether congressmen could retain reserve commissions they held at the time of their elections; he perceived no textual commitment to Congress regarding one's ability to hold an executive office, and it was those offices, rather than the congressional seats, that were at stake. But Judge Gesell's theory explicitly rested in part on the fact that the congressmen held their reserve commissions before election to Congress and on "the general rule that in the case of incompatible offices, 'acceptance of the second office vacates the first." "11s On that theory, it appears that the courts could not review the ability of a sitting vicepresident to assume an executive position.

Assuming further that the issue is justiciable, there may well be no plaintiff with standing. The Supreme Court held clearly in Reservists that being a citizen or a taxpayer does not give one standing to assert a claim under the incompatibility clause. ${ }^{116}$ But we must also consider the possibility of a challenge brought by someone who has been coerced by an order of the vice-president in her appointive role (an unlikely event if that role is one, like the White House Chief of Staff, that has coercive power only over those in government). Even in that case, standing is problematic. The incompatibility clause appears to have been based, at least principally, on fears of executive encroachment on the legislature. ${ }^{117}$ It would, at least ordinarily, be difficult for someone coerced by an order of, say, the Secretary of Defense to show how she was prejudiced by the fact that the Secretary is also the president of the Senate. ${ }^{118}$ The problem would be reversed for an objecting senator

114. Brief for Petitioners at 31-42, Reservists, 418 U.S. at 208 (No. 72-1188); Memorandum Opinion for the Counsel to the President, 1 Op. Off. Legal Counsel 242, 242 (1977) ("It is our opinion that the exclusive responsibility for interpreting and enforcing the Incompatibility Clause rests with Congress.").

115. Reservists Comm. to Stop the War v. Laird, 323 F. Supp. 833, 842 (D.D.C. 1971) (quoting in part H.R. REP. No. 885, 64th Cong., 1st Sess., at 4 (1916)), affd. mem., 495 F.2d 1075 (D.C. Cir. 1972), revd. sub nom. Schlesinger v. Reservists Comm. to Stop the War, 418 U.S. 208 (1974).

116. 418 U.S. at 209.

117. See note 76 supra and accompanying text.

118. Again, Judge Gesell's Reservists opinion is instructive. There, plaintiffs claimed standing as Reservists because of injury. "by favoritism toward Congressmen in assignments, promotion, and perquisites within the Reserves." 323 F. Supp. at 840 . Judge Gesell rejected this claim, holding, "Even were these allegations proved, it is doubtful whether plaintiffs' interests as Reservists are within the zone of those interests which the Clause was designed to protect." $323 \mathrm{~F}$. 
or representative, if one ventured forward; such a plaintiff would probably be unable to prove any nonspeculative injury arising from the fact that the president of the Senate has assumed greater executive responsibilities than previously. Moreover, the courts, which are heavily influenced by discretionary factors in deciding congressional standing cases, would be especially reluctant to intervene if the executive appointment required and received the advice and consent of the Senate, or if the Senate were deemed able to disqualify the vice-president, as a "Member" of the body, from his legislative role. ${ }^{119}$

Finally, assume that the Supreme Court holds for the plaintiffs both on these threshold issues and on the merits. It almost certainly would not grant retroactive relief that could throw the government into chaos. Comity would require as little intrusiveness as possible. Indeed, in Reservists Judge Gesell declined to issue an injunction to remove the perceived incompatibility; instead, he relied on a declaratory judgment and the hope that the congressmen would act voluntarily. ${ }^{120}$ Even if in our hypothetical case the Court ruled against the vice-president, it would almost certainly act as it did in Buckley v. Valeo. ${ }^{121}$ There, the Court invalidated the original Federal Election Commission, but followed precedents in apportionment cases by according "[t]he past acts of the Commission ... de facto validity," and by staying for a brief period the effect of the Court's judgment on the statutory duties and powers of the Commission. ${ }^{122}$

To summarize, suppose that a president, concerned about the prospect of litigation challenging the appointment of the vice-president to an executive position, asks for legal advice. A sound response might run as follows:

We have a good chance of beating a lawsuit on political question or standing grounds. If we don't win at the threshold, we're almost certain to win on the merits - there's no constitutional reason why the vicepresident cannot hold the appointive job. And even if we lose on the merits, it's almost inconceivable that the Supreme Court would retroactively invalidate any of the vice-president's orders; it would issue an injunction or declaratory judgment putting her to a choice. Then, if it's worth it to you, you could ask her to send a letter to the president pro tempore resigning as president of the Senate, and at the same time we

Supp. at 840 . See also 323 F. Supp. at 841 ("[I]f these plaintiffs cannot obtain judicial review of defendants' action, then as a practical matter no one can.").

119. For a helpful discussion of the cases involving standing of members of Congress, see 13A C. Wright, A. Miller \& E. Cooper, Federal Practice and Procedure $§ 3531.11$ (1984).

120. 323 F. Supp. at $842-43$.

121. 424 U.S. 1 (1976) (per curiam).

122. 424 U.S. at $142-43$. 
could ask for a judicial declaration that this resignation is effective. Only if that declaration is denied would she have to resign from the vice-presidency (which would give you another appointment under the twentyfifth amendment) or from the appointive office. Madame President, constitutional law does not place you at any significant risk here. 